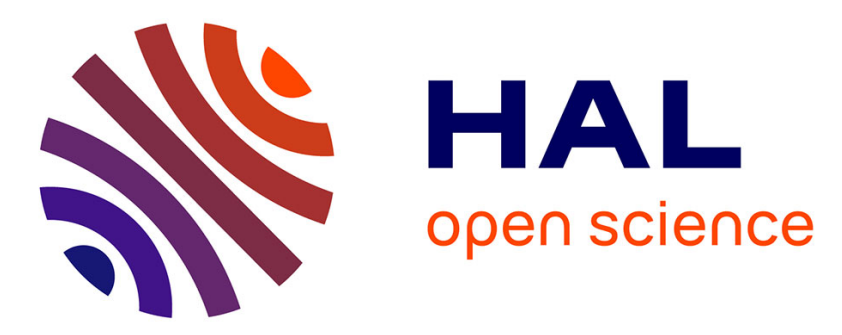

\title{
Environmental responses of the Northeast Antarctic Peninsula to the Holocene climate variability
}

\author{
Loïc Barbara, Xavier Crosta, Amy Leventer, Sabine Schmidt, Johan \\ Etourneau, Eugene Domack, Guillaume Massé
}

\section{- To cite this version:}

Loïc Barbara, Xavier Crosta, Amy Leventer, Sabine Schmidt, Johan Etourneau, et al.. Environmental responses of the Northeast Antarctic Peninsula to the Holocene climate variability. Paleoceanography, 2016, 31 (1), pp.131-147. 10.1002/2015PA002785 . hal-01266709

\section{HAL Id: hal-01266709 \\ https: / hal.sorbonne-universite.fr/hal-01266709}

Submitted on 3 Feb 2016

HAL is a multi-disciplinary open access archive for the deposit and dissemination of scientific research documents, whether they are published or not. The documents may come from teaching and research institutions in France or abroad, or from public or private research centers.
L'archive ouverte pluridisciplinaire HAL, est destinée au dépôt et à la diffusion de documents scientifiques de niveau recherche, publiés ou non, émanant des établissements d'enseignement et de recherche français ou étrangers, des laboratoires publics ou privés. 


\section{Paleoceanography}

\section{RESEARCH ARTICLE \\ 10.1002/2015PA002785 \\ Environmental responses of the Northeast Antarctic Peninsula to the Holocene climate variability}

Key Points:

- Sea ice variability related to Westerlies-ACC-Weddell Gyre interactions

- Intensification of the climate modes during the late Holocene

Correspondence to:

L. Barbara,

I.jb.barbara@gmail.com

\section{Citation:}

Barbara, L., X. Crosta, A. Leventer, S. Schmidt, J. Etourneau, E. Domack, and G. Massé (2016), Environmental responses of the Northeast Antarctic Peninsula to the Holocene climate variability, Paleoceanography, 31, doi:10.1002/2015PA002785.

Received 28 JAN 2015 Accepted 12 DEC 2015 Accepted article online 18 DEC 2015

\author{
Loïc Barbara ${ }^{1,2,3}$, Xavier Crosta ${ }^{1}$, Amy Leventer ${ }^{4}$, Sabine Schmidt ${ }^{1}$, Johan Etourneau ${ }^{1,2}$, \\ Eugene Domack ${ }^{5}$, and Guillaume Massé ${ }^{2,6}$ \\ ${ }^{1}$ Université Bordeaux, EPOC, Pessac, France, ${ }^{2}$ Sorbonne Universités (UPMC, Université Paris 06)-CNRS-IRD-MNHN, Paris, \\ France, ${ }^{3} \mathrm{Now}$ at Instituto de Geofísica, Universidad Nacional Autónoma de México, Circuito de la investigación Científica \\ s/n, Ciudad Universitaria, Coyoacán, México, ${ }^{4}$ Department of Geology, Colgate University, Hamilton, New York, USA, \\ ${ }^{5}$ College of Marine Science, University of South Florida, St. Petersburg, Florida, USA, ${ }^{6}$ Department of Biology, UMI 3376 \\ TAKUVIK, CNRS, and Université Laval, Québec City, Québec, Canada
}

\begin{abstract}
In this study, we present a unique high-resolution Holocene record of oceanographic and climatic change based on analyses of diatom assemblages combined with biomarker data from a sediment core collected from the Vega Drift, eastern Antarctic Peninsula (EAP). These data add to the climate framework already established by high-resolution marine sedimentary records from the Palmer Deep, western Antarctic Peninsula (WAP). Heavy sea ice conditions and reduced primary productivity were observed prior to 7.4 ka B.P. in relation with the proximity of the glacial ice melt and calving. Subsequent Holocene oceanographic conditions were controlled by the interactions between the Westerlies-Antarctic Circumpolar Current (ACC)-Weddell Gyre dynamics. A warm period characterized by short seasonal sea ice duration associated with a southern shift of both ACC and Westerlies field persisted until $5 \mathrm{ka}$ B.P. This warm episode was then followed by climate deterioration during the middle-to-late Holocene (5 to 1.9 ka B.P.) with a gradual increase in annual sea ice duration triggered by the expansion of the Weddell Gyre and a strong oceanic connection from the EAP to the WAP. Increase of benthic diatom species during this period was indicative of more summer/autumn storms, which was consistent with changes in synoptic atmospheric circulation and the establishment of low- to high-latitude teleconnections. Finally, the multicentennial scale variability of the Weddell Gyre intensity and storm frequency during the late Holocene appeared to be associated with the increased El Niño-Southern Oscillation frequency.
\end{abstract}

\section{Introduction}

Instrumental data show that Antarctica experienced a significant rise in atmospheric temperatures over the past 50 years, despite high spatial heterogeneity in the amplitude of the warming [Vaughan et al., 2003; Steig et al., 2009; Bromwich et al., 2013]. In particular, the Antarctic Peninsula (AP) has experienced the largest warming, with an average temperature rise of $2.5^{\circ} \mathrm{C}$ recorded at Esperanza station over the last five decades [Vaughan et al., 2003; Turner et al., 2005]. Several mechanisms such as intensification of circumpolar Westerlies [Shindell and Schmidt, 2004] and warming [Gille, 2002] and intensification of Upper Circumpolar Deep Water (UCDW) upwelling [Meredith and King, 2005] have been suggested as responsible for such warming.

This recent warming, more pronounced on the western side than the eastern side of AP [King et al., 2003], is coincident with a rapid retreat of glaciers across the peninsula [Cook et al., 2005] and the collapse of major ice shelves [Scambos et al., 2003; Hodgson et al., 2006] such as the Larsen B Ice Shelf, unprecedented in the Holocene history (the last 11.7 ka B.P.) of this glacial system [Domack et al., 2005; Rebesco et al., 2014]. The last decades were also accompanied by drastic reduction in sea ice coverage on both side of AP [Parkinson, 2002], particularly accentuated in the Bellingshausen and the western Weddell sectors where satellite data revealed a dramatic decrease winter sea ice concentration of $~ 4-10 \%$ per decade [Liu et al., 2004].

To place this recent rapid regional warming in the context of natural climate variability, researchers have used paleoclimatic archives, including marine sediment and ice cores, to reconstruct deglacial and Holocene paleoenvironmental changes. The high-resolution Palmer Deep records from the western AP (WAP) [Domack et al., 2001; Leventer et al., 2002; Taylor and Sjunneskog, 2002; Sjunneskog and Taylor, 2002; Shevenell et al., 2011; Pike et al., 2013; Etourneau et al., 2013] provide a Holocene climate framework for the WAP. These studies document Holocene climate fluctuations in relation to changes in the Westerlies intensity 



Figure 1. (a) Map of Antarctic Peninsula with bathymetry (From Ocean Data View, http://odv.awi.de) showing the location of the Vega Drift and the places quoted on the text (WAP: West Antarctic Peninsula, EAP: East Antarctic Peninsula, JRI: James Ross Island, PGC: Prince Gustav Channel). (b) Map of the Antarctic Peninsula region showing detail of oceanographic currents and different water masses (modified from Hofmann et al. [1996]; Zhou et al. [2002]; Domack et al. [2003]), position of the present day average summer and winter sea ice limits (from Fetterer et al. [2002], updated in 2007), and the average summer position of the Southern Westerlies. ACC: Antarctic Circumpolar Current; UCDW: Upper Circumpolar Deep Water; WSTW: Weddell Sea Transitional Water.

and latitudinal position, inferred variations in upwelling rates of UCDW, modulations in ENSO frequency, and the local insolation at the precessional timescale. However, a recent synthesis of existing paleoenvironmental records from AP indicates that the reconstructions in Palmer Deep are not representative of the whole region and that major climatic events throughout the Holocene might not be synchronous across the AP [Domack et al., 2003; Bentley et al., 2009]. However, the limited number of high-resolution records from the eastern AP (EAP) so far has precluded a detailed comparison of the paleoenvironmental responses in WAP and EAP in relation to common forcing factors.

This study aims to provide a new high-resolution record of Holocene sea ice and ocean variability in the northern part of the Prince Gustav Channel (PGC), localized in northern EAP. Based on diatom assemblages 
and specific diatom biomarker lipids, highly branched isoprenoids (HBI), we here attempt to infer the relationships between the different compartments of the internal climate system at the regional-to-synoptic scales during the Holocene.

\section{Oceanographic and Climatological Setting}

WAP water masses are mainly influenced by the Southern Ocean Westerlies and the Antarctic Circumpolar Current (ACC; Figure 1) [Orsi et al., 1995; Smith et al., 1999] which transports the relatively warm and salty UCDW onto the continental shelf [Smith et al., 1999] (Figure 1). In contrast, EAP water masses are mainly influenced by the clockwise oceanic circulation of the Weddell Gyre [Orsi et al., 1993]. The Weddell Gyre, driven by synoptic winds in relation with atmospheric pressure pattern along the AP and the Weddell Basin, is composed of a narrow westward branch flowing along the south coast of the Weddell Sea, a northward branch along the EAP, and a wide eastward drift following the ACC [Venegas and Drinkwater, 2001].

The cyclonic circulation carries warm UCDW into the Weddell Gyre in the eastern part of the Weddell Sea. Progressively cooled along their pathway, these waters then reach the EAP coasts in the southern part of the Weddell Sea before flowing northwards and out of the Weddell Sea into the Bransfield Strait [Orsi et al., 1993; Hellmer et al., 2009] in the form of the cold and salty Weddell Sea Transitional Water (WSTW; Figure 1) [Tokarczyk, 1987]. The WSTW interact then with the UCDW, upwelled in the WAP, in the Bransfield Strait [Tokarczyk, 1987, Garća et al., 2002; Zhou et al., 2002]. These relatively warm and nutrient-rich water masses [Hofmann et al., 1996; Smith et al., 1999] are separated from the colder and less saline Antarctic Surface Water by a permanent pycnocline. The depth and intensity of the pycnocline vary seasonally with sea ice melting/formation, solar radiation, and storm mixing [Foster and Carmack, 1976; Klinck, 1998; Robertson et al., 1985; Smith and Klinck, 2002; Annett et al., 2010]. Sea floor morphological structures suggest a westward bottom current flow in the northern part of the PGC and a circulation pattern dominated by an anticlockwise gyre around JRI [Camerlenghi et al., 2001].

The Weddell Sea is characterized by one of the most extensive sea ice regimes in the Southern Ocean [Stammerjohn and Smith, 1996]. Overall, sea ice cover reaches a maximum extent in August and a minimum extent in February [Stammerjohn and Smith, 1996]. Summer sea ice is often observed in the southern EAP as a result of transport and compaction by the Weddell Gyre [Venegas and Drinkwater, 2001; Turner et al., 2002]. However, the seasonal and interannual sea ice variability in the westernmost part of the Weddell Sea is strongly sensitive to the Weddell Gyre activity which is highly dependent on atmospheric circulation variability in relation to the Southern Annular Mode (SAM) and the El Niño-Southern Oscillation (ENSO) [Yuan, 2004; Stammerjohn et al., 2008]. These climate modes, through the modulation of sea level pressures (SLP) anomalies in the Amundsen/Bellingshausen Seas region (The Amundsen Sea Low (ASL)), strongly impact the AP pluriannual sea ice trend. Indeed, negative SLP anomalies (deepening) associated with positive SAM (+SAM) and/or La Niña events strengthen northerly winds and cyclonic activity in the AP region during autumn spring. This, in turn, leads to a reduction of the seasonal sea ice duration [Lefebvre and Goosse, 2005; Yuan, 2004; Stammerjohn et al., 2008]. The opposite scenario applies to positive SLP anomalies related to negative SAM (-SAM) and/or El Niño events.

\section{Materials and Methods}

\subsection{Core Description and Age Model}

Piston core JPC38 $\left(63.717^{\circ} \mathrm{S}, 57.411^{\circ} \mathrm{W} ; 760 \mathrm{~m}\right.$ water depth; $1986 \mathrm{~cm}$ long) was retrieved from the Vega Drift, in the northern PGC, by the RVIB Nathaniel B. Palmer during the NBP00-03 cruise in 2000, in the vicinity of the JRI (Figure 1). The sediment core is composed of diatom-poor clays and silts below $1550 \mathrm{~cm}$, laminated diatom oozes and sandy muds between $1550 \mathrm{~cm}$ and $600 \mathrm{~cm}$, and bioturbated silty diatom muds above $600 \mathrm{~cm}$ (Figure 2). The magnetic susceptibility, obtained using a Bartington MS-2C meter, displays consistently high values below $1850 \mathrm{~cm}$, decreases between $1850 \mathrm{~cm}$ and $1750 \mathrm{~cm}$, and presents uniform low values above $1750 \mathrm{~cm}$ (Figure 2).

The stratigraphy of core JPC38 is constrained by a combination of four accelerator mass spectrometer radiocarbon (AMS ${ }^{14} \mathrm{C}$ ) ages from pelecypod shell material [Willmott et al., 2006] performed at the University of Arizona (Table 1) and ${ }^{210} \mathrm{~Pb}_{\mathrm{xs}}$ activity measurement performed on low background, high-efficiency, 


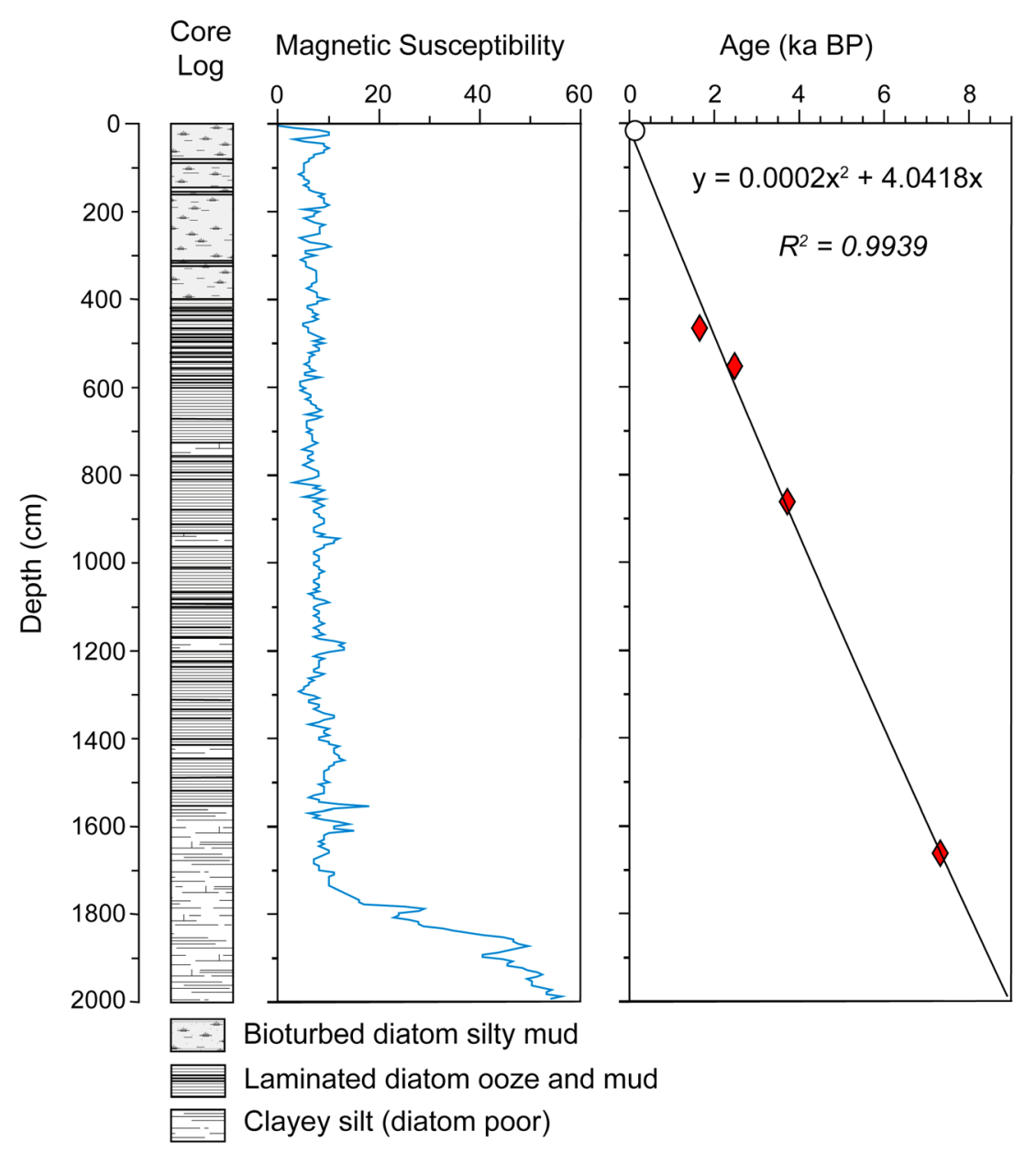

Figure 2. Synthetic log of JPC38 marine core, magnetic susceptibility curve, and age model in calendar kiloannum B.P. with the second-order polynomial best fit curve. Red diamonds and the white circle indicate dates based on ${ }^{14} \mathrm{C}$ and ${ }^{210} \mathrm{~Pb}_{\mathrm{xs}}$ (see profiles in Figure 3), respectively.

well-shaped $\gamma$ detector [Schmidt et al., 2014] (Figures 2 and 3). ${ }^{14} \mathrm{C}$ dating was calibrated to calendar years B.P. (cal B.P.) using the Calib 6.1.1 software [Stuiver et al., 2005] associated with the Marine 09 curve [Reimer et al., 2009], assuming a marine reservoir age correction of 1260 years as recommended for the AP region [Domack et al., 2001]. The ${ }^{210} \mathrm{~Pb}_{\mathrm{xs}}$ activity was measured in three horizons spanning the top $10 \mathrm{~cm}$ of core JPC38 and compared with the ${ }^{210} \mathrm{~Pb}_{\mathrm{xs}}$ activity of the corresponding multicore MTC38C (Figure 3) [Barbara et al., 2013]. The ${ }^{210} \mathrm{~Pb}_{\mathrm{xs}}$ activity in JPC38 surface sample intersects the exponential regression in the multicore MTC $38 \mathrm{C}$ at around $28 \mathrm{~cm}$, indicating an equivalent loss of sediment during coring process (Figure 3). Using the age-depth relationship calculated for MTC38C [Barbara et al., 2013], the age of JPC38 surface sediments was calculated at 1956 Common Era or " 0 cal B.P." at the timescale of the Holocene (Figure 2). The age model of core JPC38 was established using a second-order polynomial fit between

Table 1. Radiocarbon Dates and Calibrated Ages for Core JPC $38^{a}$

\begin{tabular}{lcccc} 
Laboratory Code & Core & Core Depth $(\mathrm{cm})$ & Conventional Radiocarbon Age (B. P.) & Calibrated Age (cal B. P.) \\
\hline AA44751 & JPC38 & 466 & $2904 \pm 46$ & 1652 \\
AA44752 & JPC38 & 552 & $3580 \pm 44$ & 2477 \\
AA44753 & JPC38 & 861 & $4610 \pm 55$ & 3718 \\
AA44754 & JPC38 & 1661 & $7621 \pm 46$ & 7322 \\
\hline
\end{tabular}

${ }^{\mathrm{a}}$ Results are reported with a $2 \sigma$ uncertainty. 


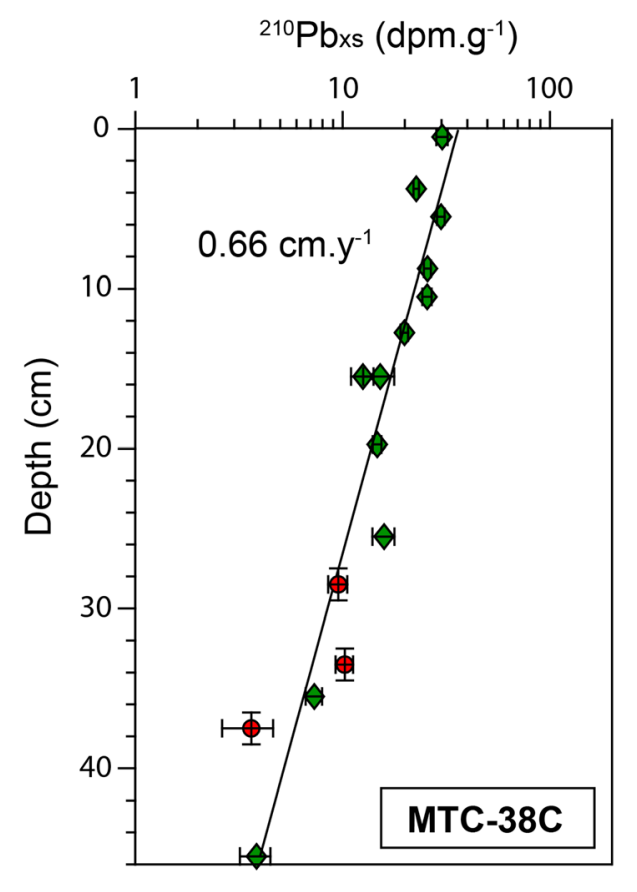

Figure 3. Excess ${ }^{210} \mathrm{~Pb}$ activity in dpm (disintegrations per minute) per gram and $1 \sigma$ error bars, with depth in MTC38C marine core (green diamonds) from Barbara et al. [2013]. The ${ }^{210} \mathrm{~Pb}_{\mathrm{xs}}$ data for JPC38 core top (red circles) were replaced onto MTC38C downcore ${ }^{210} \mathrm{~Pb}_{\mathrm{xs}}$ activities and suggest that $28 \mathrm{~cm}$ of sediment were lost from the surface of this core during the coring process. the four dates ${ }^{14} \mathrm{C}$ and the ${ }^{210} \mathrm{~Pb}_{\mathrm{xs}}$-based age $\left(R^{2}=0.9939\right.$; Figure 2). Core JPC38 covers the last 8800 years with a mean sedimentation rate of $0.21 \mathrm{~cm} /$ years. Dates are reported in the text in calibrated thousand years B.P. (ka B.P. with B.P. relative to A.D. 1950).

\subsection{Diatom Analysis}

Diatom analyses were performed at species level every $8 \mathrm{~cm}$ between the core top and $1600 \mathrm{~cm}$ and every $16 \mathrm{~cm}$ below $1600 \mathrm{~cm}$, yielding an $\sim 40$ year temporal resolution over the Holocene. Sediment treatment and slide preparation followed the technique described in Rathburn et al. [1997]. At least, 300 intact valves were counted at a magnification of 1250 using the methodology described in Crosta and Koç [2007]. Diatoms were identified to species or species group level, and their relative abundance was determined as the fraction of diatom species against the total diatom abundance in the sample. Due to the high numbers of Chaetoceros resting spores (CRS) dominating diatom assemblages in AP records [Leventer, 1991], slides were counted twice as usually performed in paleostudies [Taylor et al., 2001; Barcena et al., 2002; Heroy et al., 2008; Etourneau et al., 2013]. The slides were first counted including the CRS to calculate the total diatom concentration and the relative proportions of CRS in the diatom assemblage. Second, the slides were counted excluding CRS to assess the relative contributions of other species to the overall assemblage.

In order to extract from the diatom record the most detailed environmental information, species morphotypes were recognized. As such, the valves of Thalassiosira antarctica species were split into two morphological types (T1 and T2) following Taylor et al. [2001]. Moreover, Eucampia specific counts were performed by counting 100 specimens per slide when abundance permitted, or by counting all specimens on one slide, to evaluate the relative contribution of Eucampia antarctica var. recta ("symmetric" variety) versus Eucampia antarctica var. antarctica ("asymmetric" variety) and terminal versus intercalary valves [Fryxell, 1989; Fryxell and Prasad, 1990].

\subsection{Hydrocarbon Analysis}

The use of the specific lipid biomarkers highly branched isoprenoids (HBIs) as a sea ice proxy has been proposed and discussed by previous studies in Antarctica [Barbara et al., 2010, 2013; Denis et al., 2010; Massé et al., 2011; Collins et al., 2013; Etourneau et al., 2013]. Isotopic analyses revealed that the diunsaturated HBI ( $\mathrm{HBI}: 2)$ is synthesized by sea ice dwelling diatoms while triunsaturated isomer (HBI:3) is produced by open water diatom species in the marginal ice zone [Massé et al., 2011; Collins et al., 2013]. Furthermore, it has been proposed that the ratio of the two compounds [HBI:2]/[HBI:3] reflects the relative contribution of sea ice algae versus open water phytoplankton to the sediment [Barbara et al., 2010; Denis et al., 2010; Massé et al., 2011; Etourneau et al., 2013]. In this study, we combined the HBI proxy with diatoms assemblage data to provide a more robust Holocene reconstruction of sea ice of EAP.

Biomarkers analysis followed the technique described by Belt et al. [2007] and were performed every $4 \mathrm{~cm}$ along the core, yielding a 20 year temporal resolution over the Holocene. An internal standard (seven hexyl nonadecane) was added to each freeze dried sediment sample in order to determine $\mathrm{HBI}$ relative concentrations. Lipids were extracted using a $\mathrm{CH}_{2} \mathrm{Cl}_{2} / \mathrm{CH}_{3} \mathrm{OH}(2 / 1)$ mixture to yield a total organic extract (TOE) and elemental sulfur was removed using the tetrabutylammonium sulfite method [Jensen et al., 1977; Riis and Babel, 1999]. TOE was 


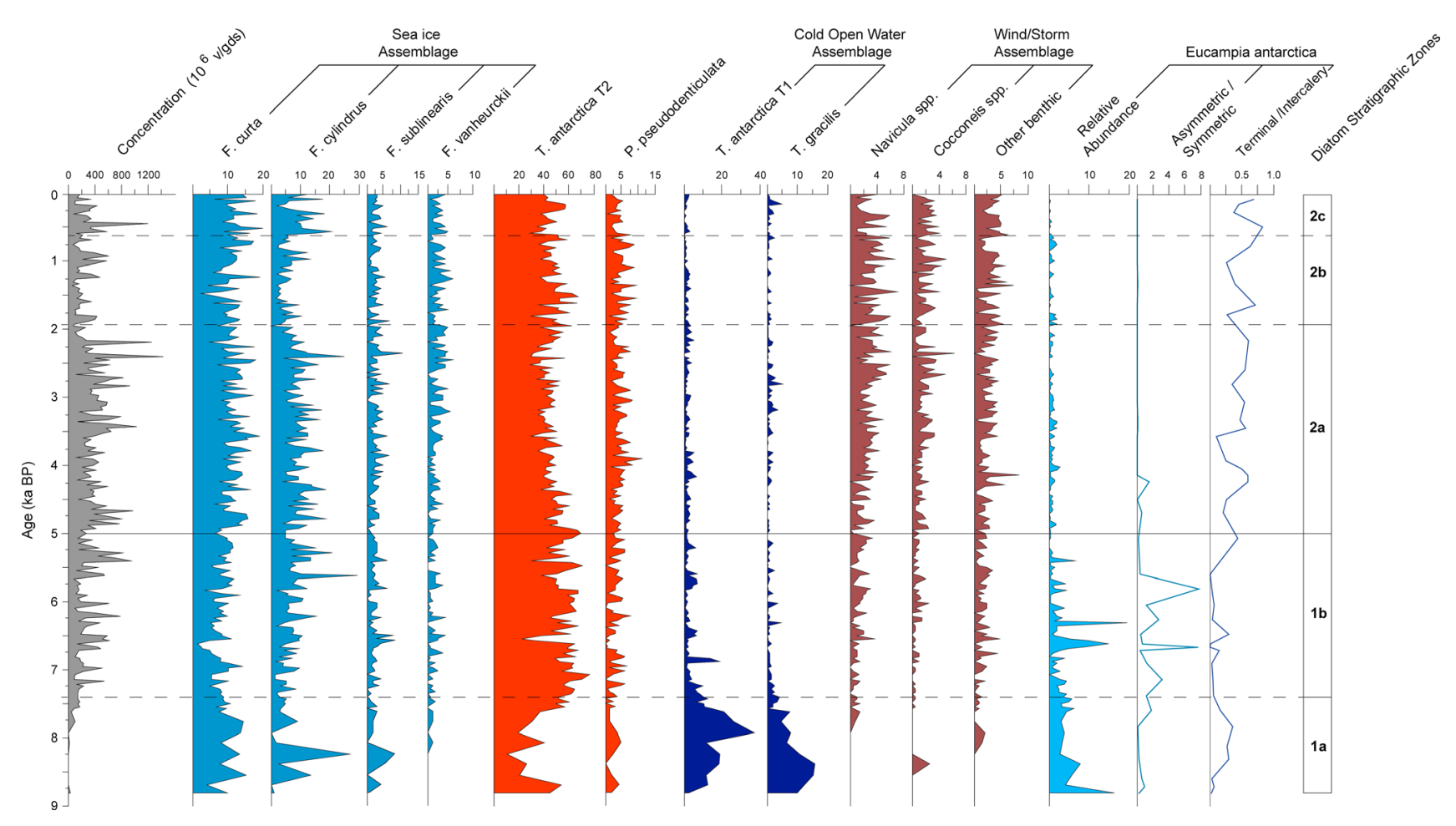

Figure 4. Total diatom concentration, relative abundance of the CRS-free assemblage of selected diatom species, and ratio Eucampia antarctica asymmetric/symmetric and terminal/intercalary forms in sediments from core JPC38. Horizontal dashed lines indicate the diatoms stratigraphic zone described in the text.

purified using open silica column chromatography. Hydrocarbons were analyzed by an Agilent 7890A gas chromatograph (GC) fitted with $30 \mathrm{~m}$ fused silica Agilent J\&C GC columns ( $0.25 \mathrm{~mm}$ ID and $0.25 \mu \mathrm{m}$ film) and coupled to an Agilent 5975C Series mass selective detector with triple axis detector. Relative abundances of $\mathrm{HBI}$ isomers were calculated on the basis of their individual GC-mass spectrometer responses relative to those of the internal standard.

\subsection{Multivariate Statistical Analysis}

Statistical analysis was performed on the diatom data set using PAST [Hammer et al., 2001], to investigate diatom community association and significant assemblage changes along the core JPC38. The statistical analyses were performed only on 17 diatom species or group of species for which relative abundances account for more than $2 \%$ within the CRS-free data set in at least one sample, and the data were logarithmically transformed to increase the statistical weight of species that occur in lower abundances. Then, Q-mode principal component analysis (PCA) was performed.

\section{Results}

\subsection{The Siliceous Fraction}

\subsubsection{Total Diatom Abundances}

Total diatom concentration in core JPC38 varied between 7 and 1400 millions of valves per gram of dry sediment $\left(.10^{6} \mathrm{v} / \mathrm{gds}\right.$; Figure 4). The JPC38 diatom record exhibited low abundance values (around $7.10^{6} \mathrm{v} / \mathrm{gds}$ ) before 7.9 ka B.P., immediately followed by a slight increase between 7.9 and 7.4 ka B.P. The highest diatom concentrations were recorded between 7 and $2.2 \mathrm{ka}$ B.P. with peak values reaching up to $\sim 1400.10^{6} \mathrm{v} / \mathrm{gds}$ at 2.4 ka B.P. and 2.2 ka B.P. Total diatom concentrations subsequently decreased again to values below $\sim 400.10^{6} \mathrm{v} / \mathrm{gds}$ after $2.2 \mathrm{ka}$ B.P., except of a short period centered at $\sim 0.5 \mathrm{ka}$ B.P., when $\sim 1200.10^{6} \mathrm{v} / \mathrm{gds}$ was encountered (Figure 4).

\subsubsection{Diatom Assemblages}

A total of 51 diatom species were identified, and the number of species in each sample ranged from 8 to 29 , with an average of 20 species. Some diatom species have been selected and grouped (Figure 4) according to their ecological affinities and according to previous published work in the same region [Buffen et al., 2007; 


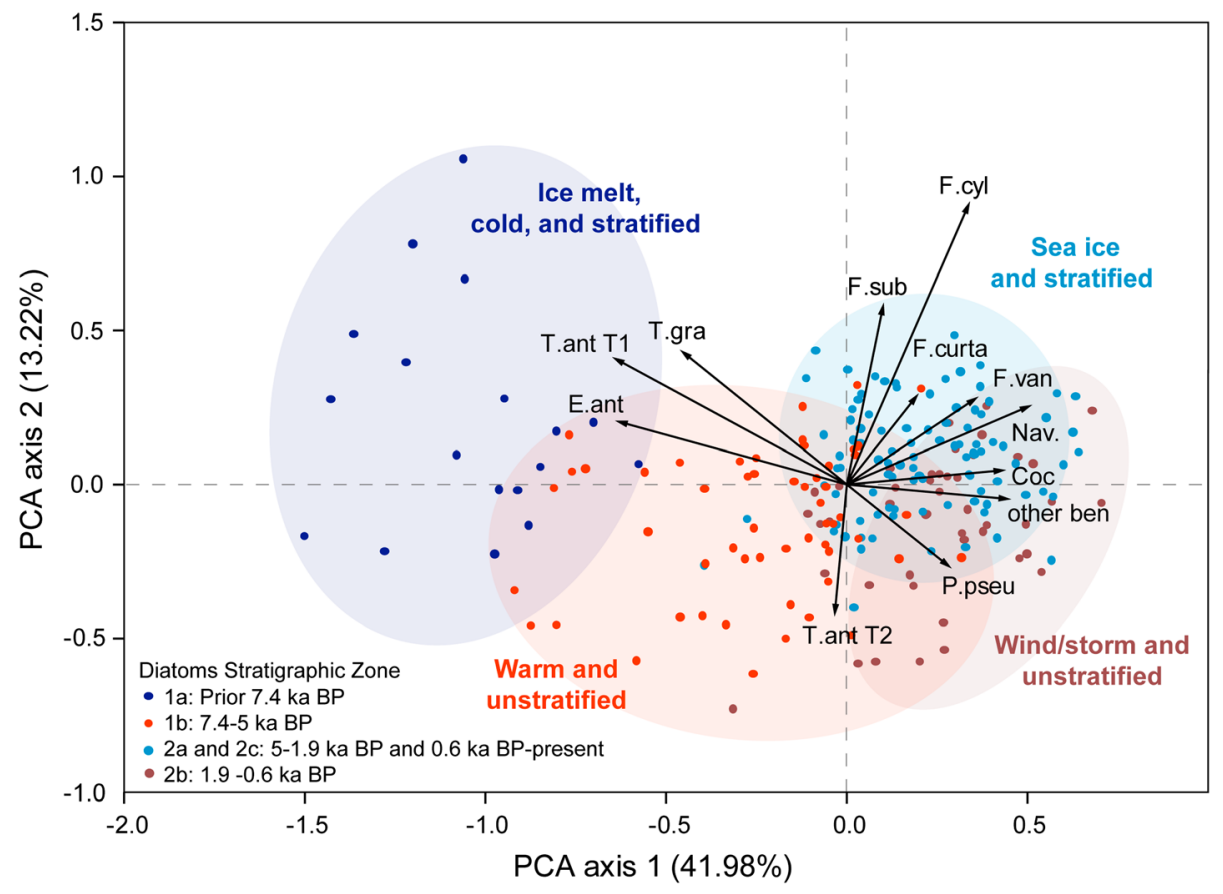

Figure 5. Biplot of the two first axes generated by principal components analysis (PCA) showing diatoms species (black arrows) and ordination of samples (colored circles). The large ellipses encompass the samples corresponding to the same diatom stratigraphic zone. T.ant T1: Thalassiosira antarctica T1, E.ant: Eucampia antarctica, T.gra: Thalassiosira gracilis, F.sub: Fragilariopsis sublinearis, F.cyl: Fragilariopsis cylindrus, F.curta: Fragilariopsis curta, Nav: Navicula spp., Coc: Cocconeis spp., Other ben: other benthic, P.pseu: Porossira pseudodenticulata, T.ant T2: Thalassiosira antarctica T2.

Barbara et al., 2013]. When excluding CRS, diatom assemblages are dominated by valves of the warm form of Thalassiosira antarctica resting spores (T2) [Taylor et al., 2001], with relative abundances ranging between $15 \%$ and $80 \%$ (Figure 4). The relative abundances of $T$. antarctica T2 were the lowest between 8.8 and $7.9 \mathrm{ka}$ B.P. and then increased rapidly to reach highest values between 7.4 and $5 \mathrm{ka}$ B.P. This period was then followed by a second interval of high T. antarctica abundance between 1.9 and $1.5 \mathrm{ka}$ B.P. By contrast, the intervals 5-1.9 ka B.P. and $1.5 \mathrm{ka}$ B.P. to the present were characterized by lower relative abundances of this species. The two periods of $T$. antarctica $\mathrm{T} 2$ highest relative abundances presented larger amplitude changes than periods of lower abundances.

Other important species contributing to the diatom assemblages were Fragilariopsis curta (2-20\%) and F. cylindrus (3-25\%), grouped within the Sea Ice Assemblage along with F. sublinearis (0-9\%) and F. vanheurckii $(0-8 \%)$. In core JPC38, the downcore records of $F$. curta and $F$. cylindrus were anticorrelated to the one of T. antarctica T2 over the entire record (Figure 4). Relative abundances of these species range between 5 and $30 \%$, with highest values encountered before $7.4 \mathrm{ka}$ B.P. and during the 5-1.9 ka B.P. and 0.6-0 ka B.P. intervals. The lowest abundances of F. curta and F. cylindrus were observed during the 7.4-5 ka B.P. and centered at $1.5 \mathrm{ka}$ B.P. F. sublinearis and F. vanheurckii relative abundances remained low along the core (Figure 4).

Thalassiosira antarctica cold form T1 (0-36\%) and T. gracilis (0-15\%), were grouped within the Cold Open Water Assemblage. The highest relative abundances of these species were observed prior to $7.4 \mathrm{ka}$ B.P. and decreased rapidly to account for $0-2 \%$ of the CRS-free assemblages until modern time (Figure 4).

Relative abundances of benthic diatoms such as Navicula spp. (0-7\%) and Cocconeis spp. (0-7\%), grouped within the Wind/Storm Assemblage, were very low prior to 7.4 ka B.P. and progressively increased until the present, showing highest variability during 5-0 ka B.P. interval (Figure 4).

Relative abundances of Eucampia antarctica (0-20\%) show highest values between 8.8-7.4 ka B.P. interval (Figure 4) and decreased progressively until 5 ka B.P. to subsequently account for $0-2 \%$ of the CRS-free assemblages until modern time. The ratio of asymmetric/symmetric form of $E$. antarctica displayed highest values during the 7.9 and $5.5 \mathrm{ka}$ B.P. period and remained very low throughout the rest of the record 


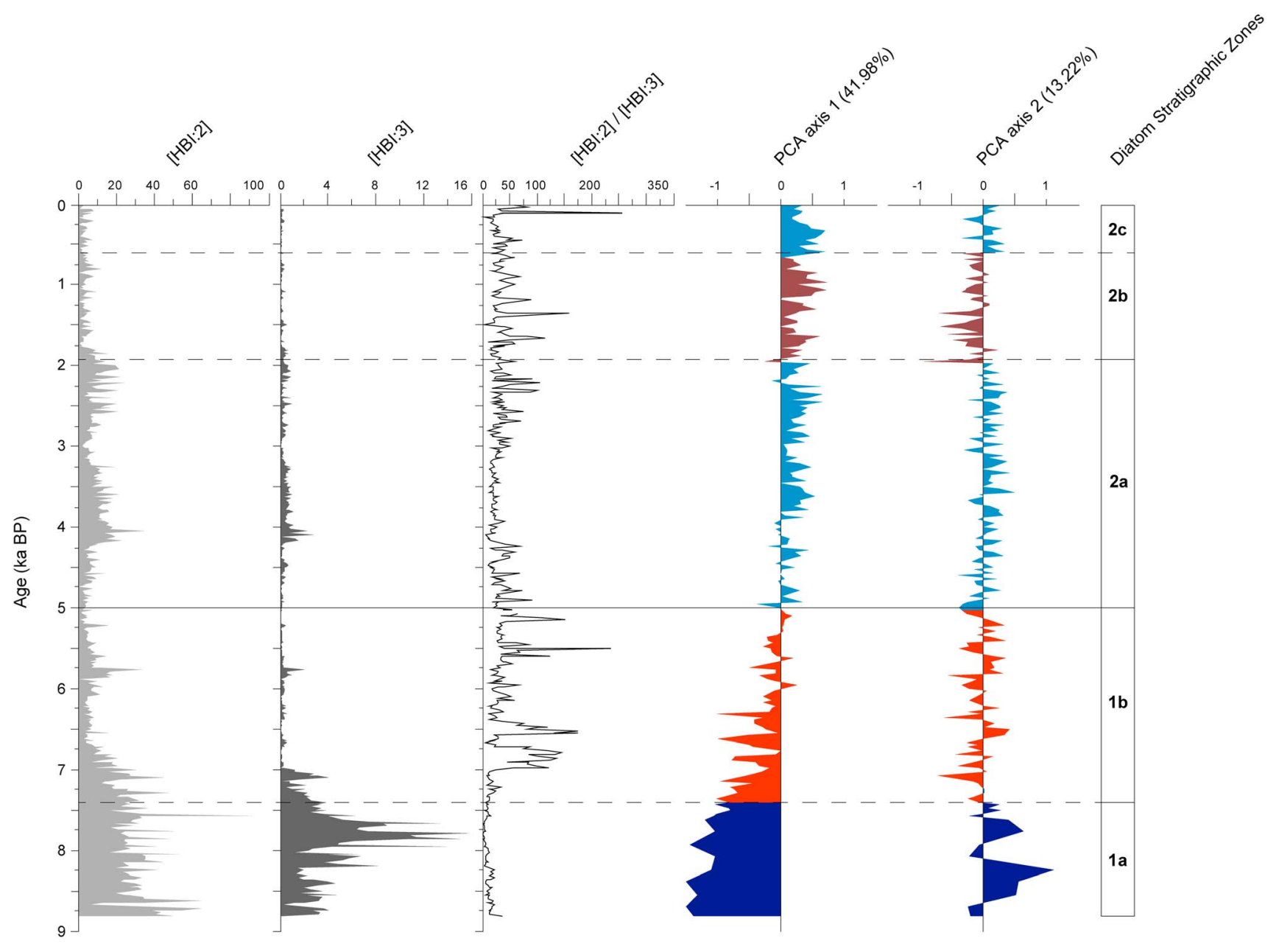

Figure 6. [HBI:2] and [HBI:3] concentrations in $\mu \mathrm{g} \mathrm{g}^{-1},[\mathrm{HBI}: 2] /[\mathrm{HBI}: 3]$ in sediments from core JPC38 and Q-mode scores of PCA axes 1 and 2, where different colors and horizontal dashed lines highlight changes between diatom stratigraphic zones.

(Figure 4). The ratio of E. antarctica terminal/intercalary valves conversely showed lowest values before $5.5 \mathrm{ka}$ B.P. and then increased during the upper part of the record (Figure 4).

\subsubsection{PCA and Diatom Stratigraphic Zones}

The PCA yielded four axes explaining $42.0 \%, 13.2 \%, 11.9 \%$, and $9.7 \%$ of the variance, respectively, for a total of $76.8 \%$. The PCA biplot (Figure 5) shows the ordination of samples and species along the two axes with the highest eigenvalues (PCA axis 1 and PCA axis 2). Diatom species and samples with a high degree of similarity are plotted close to each other on the PCA biplot. The two first axes component score changes of sign (Figure 6) illustrate the most significant assemblage transitions and display distinct stratigraphic separations. Based on the PCA biplot, two diatom stratigraphic zones and five subzones were defined following sample scores from PCA axis 1 and PCA axis 2, respectively (Figures 5 and 6). The first zone (prior to 5 ka B.P.) is characterized by negative scores on PCA axis 1. It is separated in two subzones based on positive scores on PCA axis 2 prior to 7.4 ka B.P. (zone 1a) and highly variable scores between 7.4 and 5 ka B.P. (zone 1b). Diatom assemblages are dominated by $E$. antarctica and species of the Cold Open Water Assemblage in zone $1 \mathrm{a}$ and by T. antarctica T2 in zone $1 \mathrm{~b}$. The second zone ( $5 \mathrm{ka}$ B.P. to present) is characterized by positive scores on PCA axis 1 and separated in three subzones by positive scores on PCA axis 2 during both the 5-1.9 ka B.P. and 0.6-0 ka B.P. periods (respectively, zones $2 \mathrm{a}$ and $2 \mathrm{c}$ ) and negative scores on PCA axis 2 values in the 1.9-0.6 ka B.P. period (zone 2b). The Sea Ice Assemblage represents the main diatom species over zone 2 except during zone $2 \mathrm{~b}$ when T. antarctica $\mathrm{T} 2$ and species of the Wind/Storm Assemblage increased again (Figures 5 and 6). 


\subsection{HBI Proxy in JPC38}

In core JPC38, the highest of both [HBI:2] and [HBI:3] are observed before $7.4 \mathrm{ka} \mathrm{B.P.,} \mathrm{in} \mathrm{the} \mathrm{diatom} \mathrm{strati-}$ graphic zone 1a (Figure 6). [HBI:3] peaked at approximately $7.9 \mathrm{ka}$ B.P. and decreased to reach near zero values at about $7 \mathrm{ka}$ B.P. By contrast while [HBI:2] remained high until approximately $7.4 \mathrm{ka}$ B.P. and rapidly decreased until 6.7 ka B.P. when they reached a minimum concentration. Both [HBI:2] and [HBI:3] remained low during the diatom stratigraphic zones $1 \mathrm{~b}$ and $2 \mathrm{a}$ until $4.2 \mathrm{ka}$ B.P. Concentrations of the two markers increased rapidly and remained relatively high until 1.9 ka B.P when they dropped again to very low values. [HBI:2]/[HBI:3] was lowest before 7 ka B.P when it increased abruptly (Figure 6). Subsequently, [HBI:2]/[HBI:3] varied between $\sim 25$ and $\sim 75$ with few periods when values were above 100 at 7-6.5, 5.5, 5.2, 2.2-2.3, 1.7, 1.3, and 0.2 ka B.P.

\section{Discussion}

The diatom stratigraphic zones described above reflect the oceanographic and glaciological conditions of Vega drift region during the Holocene. The PCA ordination diagram (Figure 5) allowed us to group the diatom species with the same ecology together (Figure 7) and to discuss the environmental significance of these changes in the context of regional and global climate records.

\subsection{Paleoenvironmental Reconstructions in the Northern PGC: Diatom Stratigraphic Zone 5.1.1. Proximity of Glacial Ice Melt and Heavy Sea Ice Conditions Prior to 7.4 ka B.P. (Diatom Stratigraphic Zone 1a)}

The diatom stratigraphic zone 1a corresponds to clayey silt sediments with high magnetic susceptibility values (Figure 3) and rare microfossils, typical of glacimarine sediments deposited nearby the ice shelves and heavy seasonal sea ice cover [Domack et al., 2005; Evans et al., 2005; Pudsey et al., 2006]. Low diatom abundances resulted from high supply of terrigenous particles from the receding grounded ice, diluting the biogenic fraction, and probably low primary productivity.

Zone 1a contains high concentrations of both [HBI:2] and [HBI:3] (Figure 6). Previous investigations have shown that the presence of [HBI:2] in the Antarctic sediments was linked to the development of the sympagic diatom flora when sea ice melts during spring or early summer [Belt et al., 2007; Massé et al., 2011]. As such, [HBI:2] is absent from sediments when sea ice is either absent or permanent [Collins et al., 2013]. Conversely, synthesis of [HBl:3] was only observed in diatoms thriving at the sea ice edge or in the open ocean during the spring-summer season [Massé et al., 2011; Collins et al., 2013]. In core JPC38, the concomitant high concentrations of both [HBI:2] and [HBl:3] suggest that the study area experienced heavy sea ice conditions with a very short open ocean season prior to 7.4 ka B.P.

Thalassiosira antarctica $\mathrm{T} 1$ and $T$. gracilis present lowest absolute abundances but highest relative abundances during diatom stratigraphic zone 1a (Figure 4). Grouped together within the Cold Open Water Assemblage [Barbara et al., 2013], T. gracilis and T. antarctica T1 further support the presence of open water conditions in the vicinity of the sea ice margin with cool sea surface temperatures [Taylor et al., 2001; Pike et al., 2008; Hey, 2009]. Furthermore, highest relative abundances of $E$. antarctica were also observed in stratigraphic zone 1 (Figure 4), and, when the whole downcore records is considered, this species plots nearby to the species of the Cold Open Water Assemblage on the PCA biplot (Figure 5). Eucampia antarctica thrives in iron rich environments close to sea ice (Eucampia antarctica var. recta) or open ocean islands (Eucampia antarctica var. antarctica) [Armand et al., 2005]. The occurrence of the symmetric form (Eucampia antarctica var. recta) in zone 1a suggests proximity to melting ice [Garrison et al., 1983; Burckle, 1984a]. Taken altogether, the sediment structure, low absolute diatom abundances, and the high occurrence of [HBI:2] and [HBI:3] along with high relative abundances of cold open ocean diatoms and E. antarctica depict a heavily glaciated environment with a very short sea ice free season during which surface waters were stratified due to the melting of the proximal ice shelf.

However, the diatom assemblage in stratigraphic zone 1a also contains T. antarctica T2 (average of 20\%) (Figure 7b), a species that was observed to co-occur with Fragilariopsis kerguelensis and T. lentiginosa in WAP sediments [Taylor et al., 2001] and associated with seasonally open ocean waters. The relatively low abundance, but consistent presence of $T$. antarctica T2, suggests advection from seasonally open surface water at the mouth of PGC. 

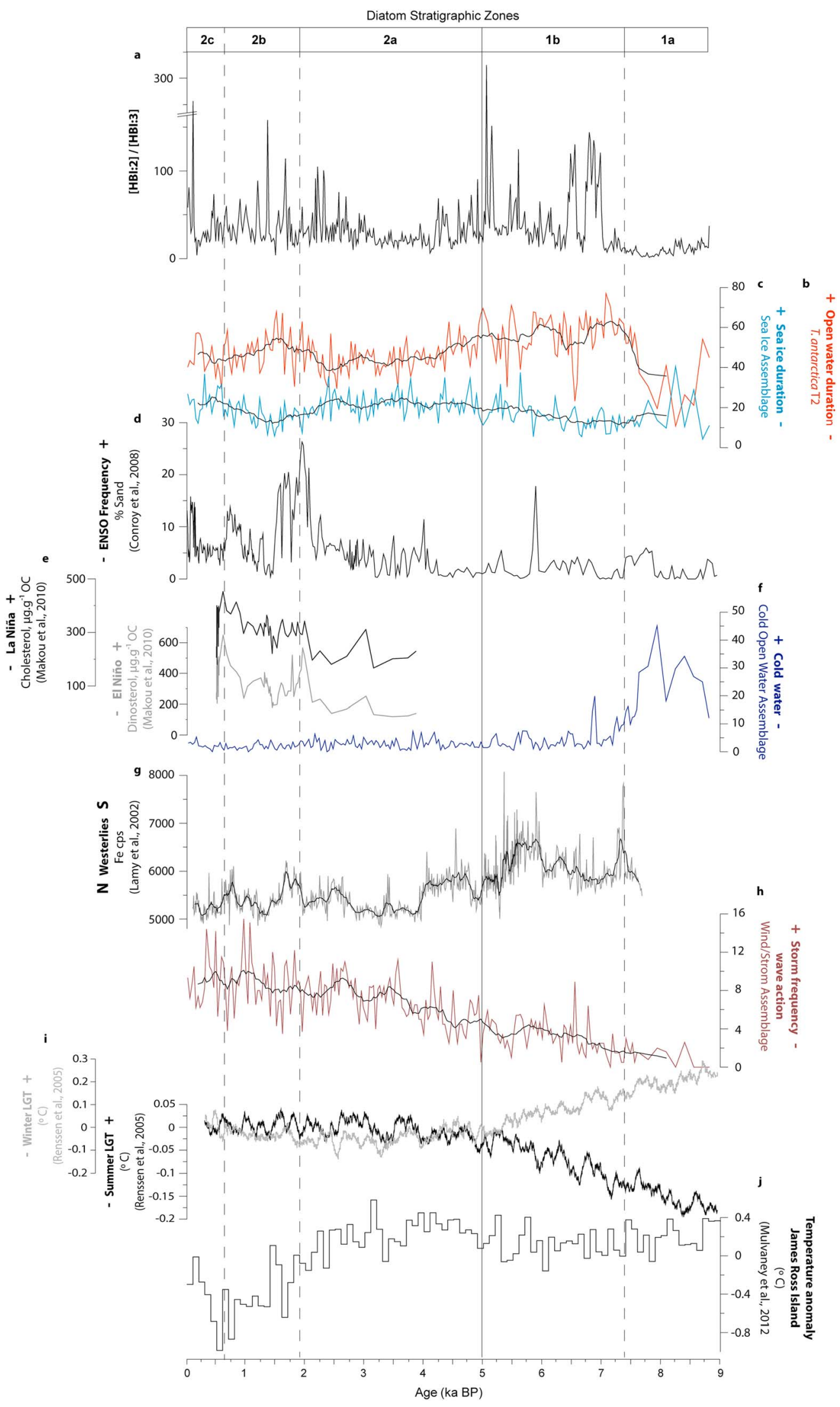

Figure 7 


\subsubsection{Hypsithermal Conditions in PGC (Diatom Stratigraphic Zone 1 b: $7.4-5$ ka B.P.)}

Diatom stratigraphic zone $1 \mathrm{~b}$ is characterized by a rapid decrease of magnetic susceptibility values along with a change in facies from clayey silt to laminated diatom ooze sediment (Figure 3). These data indicate lower terrigenous inputs of glacial plume sediments and a transition from proximal glacial ice melt to a well-established seasonal sea ice cycle with summer open marine conditions. The prevailing environmental conditions allowed for higher primary productivity than in stratigraphic zone 1 a as revealed by total diatom concentrations varying between $100.10^{6}$ and $1000.10^{6} \mathrm{v} / \mathrm{gds}$ (Figure 4).

Relative abundances of the $T$. antarctica $\mathrm{T} 2$ rapidly increased at the beginning of the diatom stratigraphic zone 1b (Figure 4 and 7b), while relative abundances of both the Cold Open Water Assemblage and E. antarctica dropped (Figure 4 and 7f). On the PCA biplot, T. antarctica T2 is positioned opposite to T. antarctica T1, T. gracilis and E. antarctica on the PCA axis 1 (Figure 5). Given the ecology of these species and the result of the PCA, we propose that a warm and less stratified water environment developed at the end of the ice shelf recession and prevailed during the 7.4-5 ka B.P. period.

The sustained high atmospheric temperatures (Figure $7 \mathrm{j}$ ) and the more southerly location of the Westerlies during this period (Figure 7g) [Lamy et al., 2001, 2002] may have resulted in the intrusion of warm UCDW waters and promoted early sea ice retreat as shown by low relative abundances of the Sea Ice Assemblage (Figures 4 and 7c). Lower sea ice concentration also is supported by the low E. antarctica terminal/intercalary ratio values during the 7.4-5 ka B.P. period (Figure 4). The low ratio values indicate the presence of long chains of $E$. antarctica var antarctica, whereby two terminal winter valves embed a variable, but greater than two, number of intercalary winter valves that can be synthesized only when winter sea ice concentration decreases [Kaczmarska et al., 1993; Whitehead et al., 2005].

A short seasonal sea ice duration reduced sea ice algae production and synthesis and export of [HBI:2] (Figure 6). Unexpectedly, [HBI:3] concentrations dropped even more during the diatom stratigraphic zone 1b, resulting in high [HBI:2]/[HBI:3] values (Figures 6 and 7a), opposite to the decrease in the Sea Ice and Cold Open Water Assemblages (Figure 4). A recent study has shown that [HBI:3] is synthesized in open waters at the marginal sea ice zone within sea ice melt-induced stratified surface waters [Collins et al., 2013].

5.1.3. Deteriorating Conditions and Extended Sea Ice Cover (Diatom Stratigraphic Zone 2a: 5-1.9 ka B.P.) Sediments of the diatom stratigraphic zone 2a are characterized by laminated diatom oozes (Figure 2). Diatom absolute abundances are highest varying between $20.10^{6}$ and $1400.10^{6} \mathrm{v} / \mathrm{gds}$ (Figure 4). The Sea Ice Assemblage presents its highest relative abundances (Figures 4 and $7 \mathrm{~b}$ ). High abundances of these species in the sediment reflect ice edge environments characterized by sea ice persisting longer during the growing season [Armand et al., 2005; Zielinski and Gersonde, 1997], which late melting stratifies the upper water column [Leventer, 1992]. [HBI:2] concentrations concomitantly increased during the stratigraphic zone 2a confirming production of sympagic diatoms and, thus, late spring sea ice melting (Figure 6). These data along with the decrease in the relative abundance of $T$. antarctica $T 2$ form indicate that the warm oceanic conditions and short sea ice duration inferred during the previous period were gradually replaced by colder conditions with greater sea ice duration (Figures 5 and $7 \mathrm{~b}$ and 7c). Higher values of the E. antarctica terminal/intercalary ratio (Figure 4) additionally demonstrate more consolidated winter sea ice. Colder and icier conditions in PGC during the 5-1.9 ka B.P. period probably resulted from a greater northward transport of cold surface water and sea ice from the south by the Weddell Gyre compacting sea ice at the core site. A greater influence of the Weddell Gyre is further supported by low [HBI:2]/[HBI:3] during this interval (Figures 6 and 7a). Indeed, investigation

Figure 7. Comparison between selected paeloenvironmental proxies from the JPC38 record, together with paleoceanographic and continental paleoclimate records from other studies. (a) The ratio of [HBI:2]/[HBI:3]. Relative abundances (\%) of (b) the T. antarctica T2 and (c) the Sea Ice Assemblage interpreted, respectively, as a proxy of open water condition duration and water column stratification. (d) Volume percent sand in a core from El Junko Crater Lake, Galapagos, $\left(0.8^{\circ} \mathrm{S}, 89.3^{\circ} \mathrm{W}\right)$ interpreted as a proxy for ENSO frequency [Conroy et al., 2008]. (e) Cholesterol and Dinosterol concentration $\left(\mu \mathrm{g} \mathrm{g}^{-1}\right.$ Organic Carbon) from Peruvian margin sediment interpreted, respectively, as proxies for La Niña and El Niño frequencies [Makou et al., 2010]. (f) Relative abundance (\%) of the Cold Open Water Assemblage interpreted as a proxy of cold water input. (g) Iron contents in core GeoB 3313-1 (with 10 point moving average) from South East Pacific $\left(41^{\circ} \mathrm{S}, 74^{\circ} \mathrm{W}\right)$ interpreted as a proxy for the position of the southern Westerlies [Lamy et al., 2001, 2002]. (h) Relative abundances (\%) of the benthic diatom group taken as a proxy for storm frequency and/or wave action. (i) Models outputs of both summer and winter anomalies of the latitudinal temperature gradients (LTG) between 20-30 and 50-60 ${ }^{\circ} \mathrm{S}$ [Renssen et al., 2005]. (j) James Ross Island reconstructed atmospheric temperature anomaly [Mulvaney et al., 2012]. The dashed lines highlight diatom stratigraphic zones in JPC38. 
of the corresponding multicore MTC38 revealed that concomitant low [HBI:2]/[HBI:3] values and high $F$. curta group relative abundances are associated with greater intensity of sea ice and fresh cold meltwater transport by the northward branch of the Weddell Gyre along the AP [Barbara et al., 2013]. In multicore MTC38 and here in JPC38 during the stratigraphic zone 2a, low [HBI:2]/[HBI:3] resulted from enhanced contribution of phytoplankton-derived organic matter (more [HBI:3] production) (Figure 6). The enhanced transport of cold freshwater and sea ice has led to a stronger stratification of the water column that promoted primary productivity in the marginal ice zone (synthesis of [HBI:3]). High phytoplankton productivity is confirmed by the strong increase in total diatom abundances (Figure 4). This strong stratification of the water column creates favorable conditions for the development of diatom species synthesizing the [HBI:3], thus explaining the greater abundances of this biomarker in the sediments and the low $[\mathrm{HBI}: 2] /[\mathrm{HBI}: 3]$ values.

\subsubsection{Unstable Conditions During the Late Holocene (Diatom Stratigraphic Zones $\mathbf{2 b}$ and 2c: 1.9 ka B.P. to Present)}

Sediments of the subzones $2 \mathrm{~b}$ and $2 \mathrm{c}$ are characterized by bioturbated diatom muds (Figure 2 ) and diatom absolute abundances decreasing back to $100-1000.10^{6} \mathrm{v} / \mathrm{gds}$ (Figure 4). The relative abundances of Wind/Storm Assemblage diatom species show a greater variability around a higher mean value in the stratigraphic zones $2 \mathrm{~b}$ and $2 \mathrm{c}$ compared to older intervals (Figures 4 and $7 \mathrm{~h}$ ) suggesting strong oscillations in summer-autumn storm frequency. These multidecadal oscillations in atmospheric dynamic are also imprinted in the $[\mathrm{HBI}: 2] /[\mathrm{HBI}: 3]$ record (Figures 6 and $7 \mathrm{a}$ ), which suggest a consequent strong variability in the Weddell Gyre intensity during the late Holocene and, thus, strong variability in the northward transport of cold freshwater and sea ice. Relative abundances of the Sea Ice Assemblage, especially F. cylindrus, dropped during the zone $2 \mathrm{~b}$ and increased again in the zone $2 \mathrm{c}$ (Figure 4). In parallel, the relative abundance of the T. antarctica $\mathrm{T} 2$ show higher values during the early zone $2 \mathrm{~b}$ subsequently decreasing since $1.5 \mathrm{ka}$ B.P., (Figures 4 and $7 \mathrm{~b}$ ).

In the zone $2 \mathrm{~b}$, higher abundances of $T$. antarctica T2 and lower abundances of the Sea Ice Assemblage suggest warmer and less icy environmental conditions especially during the 1.9-1.5 ka B.P. period. The low primary productivity during that period (Figure 4) and the PCA ordination biplot (Figure 5) suggest weak surface water stratification probably because of southward transport of warm water masses to the core site. By contrast, the zone $2 \mathrm{c}$ is characterized by higher abundances of the Sea Ice Assemblage, suggesting icier environmental conditions (Figure 5) with greater stratification and lesser influence of warm water masses, all processes enhancing diatom productivity (Figure 4). Additionally, the E. antarctica terminal/intercalary ratio (Figure 4) remained high during the late Holocene, especially zone $2 c$, suggesting a heavier winter sea ice cover, resulting from lower air temperatures over South America and Antarctica since 1300 Common Era. [Pages 2K Consortium, 2013].

\subsection{Factors Forcing the Holocene Climate Variability in EAP 5.2.1. Atmospheric Circulation and Orbital Forcing}

The long-term Holocene temperature trend in Antarctica can be explained by a response to seasonal insolation variations in the Southern Hemisphere and the heat transfer from low to high latitudes [Berger and Loutre, 1991; Renssen et al., 2005; Davis and Brewer, 2009]. Changes in the seasonal latitudinal gradient of temperature (LGT), in response to variations in seasonal latitudinal insolation gradient [Berger and Loutre, 1991], induced changes in seasonal heat transfer from low to high latitudes and, therefore, large scale atmospheric circulation [Davis and Brewer, 2009]. Winter sea ice concentrations in PGC, inferred from the E. antarctica terminal/intercalary ratio (Figure 4), shows a similar Holocene trend to the winter LGT (Figure 7i) [Renssen et al., 2005]. Stronger winter LGT during the early-to-middle Holocene enhanced the transfer of heat flux from low latitudes, hence reducing winter sea ice concentration. The weakening of the winter LGT after 5 ka B.P. reduced the winter southward atmospheric circulation and therefore the winter heat flux, allowing for greater winter sea ice concentration during this period.

In parallel, we infer a progressive increase of storm frequencies (Figure $7 \mathrm{~h}$ ) coinciding with the increase of the summer LGT over the Holocene (Figure 7i). A stronger summer LGT, in response to increasing summer latitudinal insolation gradient [Berger and Loutre, 1991], could have enhanced the summer southward atmospheric circulation [Vimeux et al., 2001; Davis and Brewer, 2009] with an increase in the intensity and number of cyclones [Carleton, 1989]. More intense cyclonic activity carried heat and moisture southward, contributing to the strengthening of the Amundsen Sea Low during this period [Kreutz et al., 2000; Mayewski et al., 2004, 2009] 
and, therefore, to an increase of summer/autumn storms frequency in the AP region [Turner et al., 1998; Simmonds and Keay, 2000]. Storm stress controlled by obliquity changes also is inferred in East Antarctica [Denis et al., 2010], suggesting important changes in atmospheric circulation pattern over the entire Southern Ocean during the middle-to-late Holocene period [Bentley et al., 2009; Mayewski et al., 2009].

\subsubsection{Westerlies-ACC-Weddell Gyre Interactions}

Reconstructions of environmental conditions during the Holocene in AP have shown that the major changes were strongly coupled to both of atmospheric and oceanic fluctuations [Bentley et al., 2009; Shevenell et al., 2011; Pike et al., 2013; Etourneau et al., 2013]. Westerlies and ACC positions might have been the main contributor to glacial ice discharge and sea ice variability in WAP during the Holocene. However, our results show that the EAP appears to have responded differently than the WAP to the atmospheric-oceanic coupling due to the presence of the Weddell Gyre.

Prior to 7.4 ka B.P., our results indicate heavy sea ice conditions with the presence of fresh and cold water (Figure 7), consistent with the impact of glacial ice melting in northern PGC. Evidence from marine sediments retrieved in coastal bays and fjords in WAP suggested that the glaciers retreat rates was rapid [Taylor et al., 2001; Bentley et al., 2005; Heroy and Anderson, 2007; Allen et al., 2010; Pike et al., 2013] following the early Holocene warm period [Masson-Delmotte et al., 2004]. It has been hypothesized that the rapid WAP ice retreat was driven by the warmer atmospheric temperature prevailing over the AP [Mulvaney et al., 2012] and by greater intrusion of warm UCDW onto the inner continental shelf due to a more southern position of the Westerlies [Shevenell and Kennett, 2002; Shevenell et al., 2011; Pike et al., 2013; Etourneau et al., 2013].

In contrast, in northern PGC, the main glacial ice retreat started around 10.6 ka B.P. [Ingólfsson et al., 2003; Domack et al., 2005] and followed on until 8.0 ka B.P. when glacial ice grounded in northern PGC began to form an ice shelf [Johnson et al., 2011; Sterken et al., 2012; Ó Cofaigh et al., 2014]. Although the southward position of the Westerlies and ACC boundary may have also contributed to the retreat of the EAP floating ice shelf, our data suggest that the northward transport of sea ice and cold surface waters by the Weddell Gyre along with large amounts of freshwater released from local glaciers have enhanced sea ice conditions and slow down EAP floating ice shelve retreat in PGC, delaying the appearance of seasonally open water conditions during spring/summer until 7.4 ka B.P.

Thereafter, the slowed down EAP ice retreat, coupled with the poleward position of the Westerlies (Figures $7 f$ and $7 \mathrm{~g}$ ), might have resulted in the contraction of the Weddell Gyre together with a deeper (and warmer) pycnocline at the northern rim of the Gyre [Martinson and lannuzzi, 2003]. The southward shift of the Westerlies, weakening the synoptic winds along the EAP coast [Stewart and Thompson, 2015], might have induced a weakening of the northward branch of the Gyre and reduced transport of fresh, cold water from the southern part of the Weddell Sea, resulting in warmer conditions in PGC in turn inducing early spring sea ice melting and late summer sea ice formation between 7.4 and 5 ka B.P. (Figures 4 and 7). Furthermore, although the modern oceanic circulation does not show evidence of a direct influence of UCDW water masses in PGC (Figure 1), a weakened northward current associated with a more southern position of both the Westerlies and the boundary of the ACC could have promoted modified UCDW occurrence onto the inner EAP continental shelf [Stewart and Thompson, 2015; Spence et al., 2014], accelerating regional ice shelf retreat and inducing a shorter sea ice season (Figure 7c). This scenario is supported by warm conditions observed during this period all over the northern part of PGC and JRI region [Johnson et al., 2011; Sterken et al., 2012; Ó Cofaigh, 2014] and the reduced intrusion of Weddell Sea Water into the Bransfield Basin from 8-5ka B.P. [Heroy et al., 2008]. The same dynamic principles, attributed to Westerlies-ACC-Weddell Gyre interactions, can explain the deteriorating conditions between 5-1.9 ka B.P. (Figures 7a and 7c) [Michalchuk et al., 2009; Sterken et al., 2012]. The Westerlies wind field and the southern boundary of the ACC shifted northward (Figure 7g) [Lamy et al., 2001, 2002], thus reducing both the UCDW upwelling in the AP area [Shevenell and Kennett, 2002; Shevenell et al., 2011; Etourneau et al., 2013] and warm water masses intrusion in northern part of EAP [Michalchuk et al., 2009], allowed for the expansion of the Weddell Gyre and promoted transport of cold freshwater and sea ice from the southwestern Weddell Sea to the core site. Cold and stratified surface water favored later sea ice melting and earlier sea ice formation, thus conducting to a shorter sea ice free season. The presence of colder surface water from the Weddell Sea was also observed in the Bransfield Bassin during this period [Heroy et al., 2008] and is consistent with an expansion of the Weddell Gyre and the establishment of a strong oceanic connection from the EAP to the WAP. 


\subsubsection{Intensification of the Climate Modes}

While seasonal LGT and Westerlies position stayed relatively constant during the late Holocene (Figures $7 \mathrm{~g}$ and 7i) [Renssen et al., 2005; Lamy et al., 2002], we observe a strong multidecadal to centennial variability in both of the sea ice regime (Figures 7a-7c) and wind and/or storm frequency (Figure 7h) after 1.9 ka B.P. This strong variability provides evidence that the Weddell Gyre intensity and the spring/summer sea ice condition in EAP were connected, probably in association with a strong atmospheric forcing. Such a strong climate variability has been already identified in AP and associated to increased ENSO frequency [Bentley et al., 2009; Shevenell et al., 2011; Pike et al., 2013; Etourneau et al., 2013], documented to begin around 4 ka B.P. [Moy et al., 2002; Riedinger et al., 2002; Rein et al., 2005; Conroy et al., 2008].

However, while most of reconstructions of sea surface conditions in WAP described a single cooling trend through the last 2 ka B.P. [Bentley et al., 2009; Shevenell et al., 2011; Pike et al., 2013; Etourneau et al., 2013] in line with the pronounced cooling atmospheric temperature (Figure 7j) [Mulvaney et al., 2012], our results indicate a warm period around 1.9-1.5 ka B.P. (Figures 7b and 7c). This period is concomitant with the strong ENSO frequency associated with more La Niña events (Figures 7d and 7e) [Conroy et al., 2008; Makou et al., 2010] and prevailing +SAM [Gomez et al., 2011]. We suggest that these +SAM conditions with several strong La Niña events during that period promoted a strengthening of the northerly winds during both autumn and spring, leading to early sea ice retreat in spring and late sea ice formation in the autumn as evidenced today [Stammerjohn et al., 2008]. Our results show that environmental conditions did not follow a similar trend in response to the regional atmospheric temperatures (Figure 7j) [Mulvaney et al., 2012] in both side of AP and appeared to be more sensitive to the southern climate modes variability in EAP than in WAP during the late Holocene, probably through their impact on the Weddell Gyre circulation.

\section{Conclusion}

The marine sediment core JPC38 from the Vega Drift provides a new high-resolution Holocene climate record of variability and oceanographic conditions on the eastern side of the AP. Diatoms assemblage and multivariate statistical analyses along with specific biomarkers provide a robust reconstruction, and new insights into the past 8 ka B.P. climate history of the AP.

Prior to 7.4 ka B.P., the proximity to the glacial ice promoted high terrigenous sediment input to the site. Heavy glacial and sea ice conditions and the presence of fresh and cold water in the Vega Drift region reduced marine productivity. Although the southward migration of both the Westerlies and the ACC may have contributed to the ice retreat of both WAP and EAP, the northward transport of sea ice and cold surface waters by the Weddell Gyre likely increased sea ice extent and slowed down EAP ice retreat in PGC during the early Holocene. Optimum climatic conditions occurred in PGC during the 7.4 to 5 ka B.P. interval and are associated with a southward shift of both ACC and Westerlies and resulting in a reduction of the Weddell Gyre transport. In contrast, the 5-1.9 ka B.P. period experienced cooler conditions. The northward migration of the ACC might have allowed for the expansion of the Weddell Gyre, promoting transport of cold freshwater and sea ice from the southwestern Weddell Sea to the core site and establishing a strong oceanic connection from the EAP to the WAP. In parallel, the increase of benthic diatom species during the middle-to-late Holocene period (7.4-1.9 ka B.P.) indicated an increase of summer/autumn storms frequency in relation with important changes in the synoptic atmospheric circulation, which is controlled by obliquity changes. The establishment of strong climate teleconnections between low and high latitudes marked this period and seems more pronounced in EAP than in WAP. During the late Holocene, our results did not demonstrate a single cooling trend as observed in WAP but suggested a warm period around 1.9-1.5 ka B.P., related to the concomitant influence of strong ENSO frequency and prevalent positive anomalies of the SAM.

The results presented here reinforce previous paleoceanographic reconstructions of AP area and provide additional insights into the regional Holocene history of the ocean-ice-atmosphere interactions. The data provide evidence that strong atmospheric teleconnections between Pacific low latitudes and EAP during the middle-to-late Holocene modulated sea surface conditions and primary productivity in relation with the Weddell Gyre intensity. Although this strong multidecadal to centennial scale climate variability in PGC coincided with the initiation of strong ENSO variability, high-resolution reconstructions of environmental conditions to decipher the interaction between the ice-ocean-atmosphere systems around the AP during the late Holocene are required to further assess their interactions. 


\section{Acknowledgments}

We thank C. Charles and the two anonymous reviewers for their constructive comments. The sediment cores were collected during cruise NBP0003; we thank the captain and crew, shipboard staff and scientific party, and the staff at the Antarctic Marine Geology Research Facility. This work was supported by the NSF Office of Polar Programs and was supported financially by the French ANR CLIMICE and the ERC ICEPROXY (20441). This work also contributes to the HOLOCLIP project, a joint research project of the ESF PolarCLIMATE program and the European Union's Seventh Framework programme (FP7/20072013) under grant agreement 243908 , "Past4Future, Climate change-Learning from the past climate". This is HOLOCLIP contribution no. 26. This is a Past4Future contribution.

\section{References}

Allen, C. S., L. Oakes-Fretwell, J. B. Anderson, and D. A. Hodgson (2010), A record of Holocene glacial and oceanographic variability in Neny Fjord, Antarctic Peninsula, Holocene, 20(4), 551-564.

Annett, A. L., D. S. Carson, X. Crosta, A. Clarke, and R. S. Ganeshram (2010), Seasonal progression of diatom assemblages in surface waters of Ryder Bay, Antarct. Polar Biol., 33(1), 13-29.

Armand, L. K., X. Crosta, O. Romero, and J.-J. Pichon (2005), The biogeography of major diatom taxa in Southern Ocean sediments, Palaeogeogr. Palaeoclimatol. Palaeoecol., 223(1-2), 93-126.

Barbara, L., X. Crosta, G. Massé, and O. Ther (2010), Deglacial environments in eastern Prydz Bay, East Antarctica, Quat. Sci. Rev., 29(19-20), 2731-2740.

Barbara, L., X. Crosta, S. Schmidt, and G. Massé (2013), Diatoms and biomarkers evidence for major changes in sea ice conditions prior the instrumental period in Antarctic Peninsula, Quat. Sci. Rev., 79, 99-110.

Barcena, M. A., E. Isla, A. Plaza, J. Flores, F. J. Sierro, P. Masqué, J. A. Sanchez-Cabeza, and A. Palanques (2002), Bioaccumulation record and paleoclimatic significance in the Western Bransfield Strait. The last 2000 years, Deep Sea Res., Part II, 49, 935-950.

Belt, S. T., G. Massé, S. J. Rowland, M. Poulin, C. Michel, and B. LeBlanc (2007), A novel chemical fossil of palaeo sea ice: IP25, Org. Geochem., $38(1), 16-27$.

Bentley, M. J., D. A. Hodgson, D. E. Sugden, S. J. Roberts, J. A. Smith, M. J. Leng, and C. Bryant (2005), Early Holocene retreat of the George VI Ice Shelf, Antarctic Peninsula, Geology, 33(3), 173.

Bentley, M. J., et al. (2009), Mechanisms of Holocene palaeoenvironmental change in the Antarctic Peninsula region, Holocene, 19(1), 51-69. Berger, A., and M. F. Loutre (1991), Insolation values for the climate of the last 10 million years, Quat. Sci. Rev., 10(4), 297-317.

Bromwich, D. H., J. P. Nicolas, A. J. Monaghan, M. A. Lazzara, L. M. Keller, G. A. Weidner, and A. B. Wilson (2013), Central West Antarctica among the most rapidly warming regions on Earth, Nat. Geosci., 6(2), 139-145.

Buffen, A., A. Leventer, A. Rubin, and T. Hutchins (2007), Diatom assemblages in surface sediments of the northwestern Weddell Sea, Antarctic Peninsula, Mar. Micropaleontol., 62(1), 7-30.

Burckle, L. H. (1984a), Diatom distribution and paleoceanographic reconstruction in the Southern Ocean-Present and last glacial maximum, Mar. Micropaleontol., 9, 241-261.

Camerlenghi, A., E. Domack, M. Rebesco, R. Gilbert, S. Ishman, A. Leventer, S. Brachfeld, and A. Drake (2001), Glacial morphology and post-glacial contourites in northern Prince Gustav Channel (NW Weddell Sea, Antarctica), Mar. Geophys. Res., 22(5-6), 417-443.

Carleton, A. M. (1989), Antarctic sea-ice relationships with indices of the atmospheric circulation of the Southern Hemisphere, Clim. Dyn., 3(4), 207-220.

Collins, L. G., C. S. Allen, J. Pike, D. A. Hodgson, K. Weckström, and G. Massé (2013), Evaluating highly branched isoprenoid (HBI) biomarkers as a novel Antarctic sea-ice proxy in deep ocean glacial age sediments, Quat. Sci. Rev., 79, 87-98.

Conroy, J. L., J. T. Overpeck, J. E. Cole, T. M. Shanahan, and M. Steinitz-Kannan (2008), Holocene changes in eastern tropical Pacific climate inferred from a Galápagos lake sediment record, Quat. Sci. Rev., 27(11-12), 1166-1180.

Cook, A. J., A. J. Fox, D. G. Vaughan, and J. G. Ferrigno (2005), Retreating glacier fronts on the Antarctic Peninsula over the past half-century, Science, 308(5721), 541-4.

Crosta, X., and N. Koç (2007), Chapter eight diatoms: From micropaleontology to isotope geochemistry, Dev. Mar. Geol., 1, $327-369$.

Davis, B. A. S., and S. Brewer (2009), Orbital forcing and role of the latitudinal insolation/temperature gradient, Clim. Dyn., 32(2-3), 143-165.

Denis, D., X. Crosta, L. Barbara, G. Massé, H. Renssen, O. Ther, and J. Giraudeau (2010), Sea ice and wind variability during the Holocene in East Antarctica: Insight on middle-high latitude coupling, Quat. Sci. Rev., 29(27-28), 3709-3719.

Domack, E., A. Leventer, R. Dunbar, F. Taylor, S. Brachfeld, and C. Sjunneskog (2001), Chronology of the Palmer Deep site, Antarctic Peninsula: A Holocene palaeoenvironmental reference for the circum-Antarctic, Holocene, 11(1), 1-9.

Domack, E., D. Duran, A. Leventer, S. Ishman, S. Doane, S. McCallum, D. Amblas, J. Ring, R. Gilbert, and M. Prentice (2005), Stability of the Larsen B ice shelf on the Antarctic Peninsula during the Holocene epoch, Nature, 436(7051), 681-5.

Domack, E. W., A. Burnett, and A. Leventer (2003), Environmental setting of the Antarctic Peninsula, in Antarctic Peninsula Climate Variability: Historical and Paleoenvironmental Perspectives, edited by E. Domack, pp. 1-13, AGU, Washington, D. C.

Etourneau, J., et al. (2013), Holocene climate variations in the western Antarctic Peninsula: Evidence for sea ice extent predominantly controlled by changes in insolation and ENSO variability, Clim. Past, 9(4), 1431-1446.

Evans, J., C. J. Pudsey, C. Ó. Cofaigh, P. Morris, and E. Domack (2005), Late Quaternary glacial history, flow dynamics and sedimentation along the eastern margin of the Antarctic Peninsula Ice Sheet, Quat. Sci. Rev., 24(5-6), 741-774.

Fetterer, F., K. Knowles, W. Meier, and M. Savoie (2002), updated daily. Sea ice index. Boulder, Colorado USA: National Snow and Ice Data Center. Digital media.

Foster, T. D., and E. C. Carmack (1976), Temperature and salinity structure in the Weddell Sea, J. Phys. Oceanogr., 6(1), 36-44.

Fryxell, G. A. (1989), Marine phytoplankton at the Weddell Sea ice-edge: Seasonal changes at the specific level, Polar Biol., 10, 1-18.

Fryxell, G. A., and A. K. S. K. Prasad (1990), Eucampia antarctica var. recta (Mangin) stat. nov. (Biddulphiaceae Bacillariophyceae): Life stages at the Weddell sea ice edge, Phycologia, 29(1), 27-38.

Garćia, M. A., C. G. Castro, A. F. Ríos, M. D. Doval, G. Rosón, D. Gomis, and O. López (2002), Water masses and distribution of physico-chemical properties in the Western Bransfield Strait and Gerlache Strait during Austral summer 1995/96, Deep Sea Res., Part II, 49(4-5), 585-602.

Garrison, D. L., S. F. Ackley, and K. R. Buck (1983), A physical mechanism for establishing algal populations in frazil ice, Nature, $306(5941), 363-365$.

Gille, S. T. (2002), Warming of the Southern Ocean since the 1950s, Science, 295(5558), 1275-1277.

Gomez, B., L. Carter, A. R. Orpin, K. M. Cobb, M. J. Page, N. A. Trustrum, and A. S. Palmer (2011), ENSO/SAM interactions during the middle and late Holocene, Holocene, 22(1), 23-30.

Hammer, Ø., D. A. T. Harper, and P. D. Ryan (2001), PAST: Paleontological statistics software package for education and data análisis, Palaeontol. Electron., 4(1), 9. [Available at http://palaeo-electronica.org/2001_1/past/issue1_01.htm.]

Hellmer, H. H., F. Kauker, and R. Timmermann (2009), Weddell Sea anomalies: Excitation, propagation, and possible consequences, Geophys. Res. Lett., 36, L12605, doi:10.1029/2009GL038407.

Heroy, D. C., and J. B. Anderson (2007), Radiocarbon constraints on Antarctic Peninsula Ice Sheet retreat following the Last Glacial Maximum (LGM), Quat. Sci. Rev., 26, 3286-3297.

Heroy, D. C., C. Sjunneskog, and J. B. Anderson (2008), Holocene climate change in the Bransfield Basin, Antarctic Peninsula: Evidence from sediment and diatom analysis, Antarct. Sci., 20(01), 69-87.

Hey, A. R. (2009), Palaeoclimate Reconstructions From the Antarctic Peninsula; Linking Marine and Terrestrial Records, 487 pp., PhD thesis, Cardiff Univ. 
Hodgson, D. A., E. Verleyen, A. H. Squier, K. Sabbe, B. J. Keely, K. M. Saunders, and W. Vyverman (2006), Interglacial environments of coastal east Antarctica: comparison of MIS 1 (Holocene) and MIS 5e (Last Interglacial) lake-sediment records, Quat. Sci. Rev., 25(1-2), $179-197$.

Hofmann, E. E., J. M. Klinck, C. M. Lascara, and D. A. Smith (1996), Water mass distribution and circulation west of the Antarctic Peninsula and including Bransfield Strait, in Foundations for Ecological Research West of the Antarctic Peninsula, edited by R. M. Ross, E. E. Hofmann, and L. B. Quetin, pp. 61-80, AGU, Washington D. C.

Ingólfsson, Ó., C. Hjort, and O. Humlum (2003), Glacial and climate history of the Antarctic Peninsula since the Last Glacial Maximum, Arctic, Antarct. Alp. Res., 35(2), 175-186.

Jensen, S., L. Renberg, and L. Reutergardh (1977), Residue analysis of sediment and sewage sludge for organochlorines in the presence of elemental sulfur, Anal. Chem., 49(2), 316-318.

Johnson, J. S., M. J. Bentley, S. J. Roberts, S. A. Binnie, and S. P. H. T. Freeman (2011), Holocene deglacial history of the northeast Antarctic Peninsula-A review and new chronological constraints, Quat. Sci. Rev., 30(27-28), 3791-3802.

Kaczmarska, I., N. E. Barbrick, J. M. Ehrman, and G. P. Cant (1993), Eucampia Index as an indicator of the Late Pleistocene oscillations of the winter sea-ice extent at the ODP Leg 119 Site 745B at the Kerguelen Plateau, Hydrobiologia, 269-270(1), $103-112$.

King, J. C., J. Turner, G. J. Marshall, W. M. Connolley, and T. A. Lachlan-Cope (2003), Antarctic Peninsula climate variability and its causes as revealed by analysis of instrumental records, in Antarctic Peninsula Climate Variability: Historical and Paleoenvironmental Perspectives, edited by E. Domack et al., pp. 17-30, AGU, Washington D. C.

Klinck, J. M. (1998), Heat and salt changes on the continental shelf west of the Antarctic Peninsula between January 1993 and January 1994 , J. Geophys. Res., 103(C4), 7617-7636, doi:10.1029/98JC00369.

Kreutz, K. J., P. A. Mayewski, I. I. Pittalwala, L. D. Meeker, M. S. Twickler, and S. I. Whitlow (2000), Sea level pressure variability in the Amundsen Sea region inferred from a West Antarctic glaciochemical record, J. Geophys. Res., 105(D3), 4047-4059.

Lamy, F., D. Hebbeln, U. Röhl, and G. Wefer (2001), Holocene rainfall variability in southern Chile: A marine record of latitudinal shifts of the Southern Westerlies, Earth Planet. Sci. Lett., 185(3-4), 369-382.

Lamy, F., C. Rühlemann, D. Hebbeln, and G. Wefer (2002), High- and low-latitude climate control on the position of the southern Peru-Chile Current during the Holocene, Paleoceanography, 17(2), 10-16, doi:10.1029/2001PA000727.

Lefebvre, W., and H. Goosse (2005), Influence of the Southern Annular Mode on the sea ice-ocean system: The role of the thermal and mechanical forcing, Ocean Sci. Discuss., 2(3), 299-329.

Leventer, A. (1991), Sediment trap diatom assemblages from the northern Antarctic Peninsula region, Deep Sea Res., Part A, 38(8-9), 1127-1143.

Leventer, A. (1992), Modern distribution of diatoms in sediments from the George V Coast, Antarctica, Mar. Micropaleontol., 19(4), 315-332. Leventer, A., E. Domack, A. Barkoukis, B. McAndrews, and J. Murray (2002), Laminations from the Palmer Deep: A diatom-based interpretation, Paleoceanography, 17(3), 8002, doi:10.1029/2001PA000624.

Liu, J., J. A. Curry, and D. G. Martinson (2004), Interpretation of recent Antarctic sea ice variability, Geophys. Res. Lett., 31, L02205, doi:10.1029/ 2003 GL018732.

Makou, M. C., T. I. Eglinton, D. W. Oppo, and K. A. Hughen (2010), Postglacial changes in El Nino and La Nina behavior, Geology, 38(1), 43-46.

Martinson, D. G., and R. A. lannuzzi (2003), Spatial/temporal patterns in Weddell Weddell Gyre characteristics and their relationship to global climate, J. Geophys. Res., 108(C4), 8083, doi:10.1029/2000JC000538.

Massé, G., S. T. Belt, X. Crosta, S. Schmidt, I. Snape, D. N. Thomas, and S. J. Rowland (2011), Highly branched isoprenoids as proxies for variable sea ice conditions in the Southern Ocean, Antarct. Sci., 23(05), 487-498.

Masson-Delmotte, V., B. Stenni, and J. Jouzel (2004), Common millennial-scale variability of Antarctic and Southern Ocean temperatures during the past 5000 years reconstructed from the EPICA Dome C ice core, Holocene, 14(2), 145-151.

Mayewski, P. A., et al. (2004), Holocene climate variability, Quat. Res, 62(3), 243-255.

Mayewski, P. A., et al. (2009), State of the Antarctic and Southern Ocean climate system, Rev. Geophys., 47, RG1003, doi:10.1029/2007RG000231.

Meredith, M. P., and J. C. King (2005), Rapid climate change in the ocean west of the Antarctic Peninsula during the second half of the 20 th century, Geophys. Res. Lett., 32, L19604, doi:10.1029/2005GL024042.

Michalchuk, B. R., J. B. Anderson, J. S. Wellner, P. L. Manley, W. Majewski, and S. Bohaty (2009), Holocene climate and glacial history of the northeastern Antarctic Peninsula: The marine sedimentary record from a long SHALDRIL core, Quat. Sci. Rev., 28(27-28), 3049-3065

Moy, C. M., G. O. Seltzer, D. T. Rodbell, and D. M. Anderson (2002), Variability of El Niño/Southern Oscillation activity at millennial timescales during the Holocene epoch, Nature, 420(6912), 162-5.

Mulvaney, R., N. J. Abram, R. C. A. Hindmarsh, C. Arrowsmith, L. Fleet, J. Triest, L. C. Sime, O. Alemany, and S. Foord (2012), Holocene climate and ice-shelf history, Nature, 488(7414).

Ó Cofaigh, C., et al. (2014), Reconstruction of ice-sheet changes in the Antarctic Peninsula since the Last Glacial Maximum, Quat. Sci. Rev., 100, 87-110.

Orsi, A. H., W. D. Nowlin, and T. Whitworth (1993), On the circulation and stratification of the Weddell Gyre, Deep Sea Res., Part l, 40(1), 169-203.

Orsi, A. H., T. Whitworth, and W. D. Nowlin (1995), On the meridional extent and fronts of the Antarctic Circumpolar Current, Deep Sea Res., Part l, 42(5), 641-673.

PAGES 2k Consortium (2013), Continental-scale temperature variability during the past two millennia, Nat. Geosci., 6(5), 339-346.

Parkinson, C. L. (2002), Trends in the length of the Southern Ocean sea-ice season, 1979-99, Ann. Glaciol., 34(1), 435-440.

Pike, J., C. S. Allen, A. Leventer, C. E. Stickley, and C. J. Pudsey (2008), Comparison of contemporary and fossil diatom assemblages from the western Antarctic Peninsula shelf, Mar. Micropaleontol., 67(3-4), 274-287.

Pike, J., G. E. A. Swann, M. J. Leng, and A. M. Snelling (2013), Glacial discharge along the west Antarctic Peninsula during the Holocene, Nat Geosci., 6(2), 1-5.

Pudsey, C. J., J. W. Murray, P. Appleby, and J. Evans (2006), Ice shelf history from petrographic and foraminiferal evidence, Northeast Antarctic Peninsula, Quat. Sci. Rev., 25(17-18), 2357-2379.

Rathburn, A. E., J. J. Pichon, M. A. Ayress, and P. De Deckker (1997), Microfossil and stable isotope evidence for changes Late Holocene paleoproductivity and paleoceanographic conditions in the Prydz Bay region of Antarctica, Palaeogeogr. Palaeoclimatol. Palaeoecol., 131, 485-510.

Rebesco, M., et al. (2014), Boundary condition of grounding lines prior to collapse, Larsen-B Ice Shelf, Antarctica, Science, 345(6202), 1354-1358.

Reimer, P. J., et al. (2009), IntCal09 and Marine09 radiocarbon age calibration curves, 0-50,000 years cal BP, Radiocarbon, 51, 1111-1150.

Rein, B., A. Lückge, L. Reinhardt, F. Sirocko, A. Wolf, and W.-C. Dullo (2005), El Niño variability off Peru during the last 20,000 years, Paleoceanography, 20, PA4003, doi:10.1029/2004PA001099. 
Renssen, H., H. Goosse, T. Fichefet, V. Masson-Delmotte, and N. Koc (2005), Holocene climate evolution in the high-latitude Southern Hemisphere simulated by a coupled atmosphere sea ice ocean vegetation model, Holocene, 7, 951-964.

Riedinger, M. A., M. Steinitz-Kannan, W. M. Last, and M. Brenner (2002), A -6100 14C yr record of El Niño activity from the Galápagos Islands, J. Paleolimnol., 27(1), 1-7.

Riis, V., and W. Babel (1999), Removal of sulfur interfering in the analysis of organochlorines by GC-ECD, Analyst, 124(12), 1771-1773. Robertson, R., L. Padman, and G. D. Egbert (1985), Tides in the Weddell Sea, in Ocean, Ice, and Atmosphere: Interactions at the Antarctic Continental Margin, edited by S. S. Jacobs and R. F. Weiss, pp. 341-369, AGU, Washington, D. C.

Scambos, T., C. Hulbe, and M. Fahnestock (2003), Climate-induced ice shelf disintegration in the Antarctic Peninsula, in Antarctic Peninsula Climate Variability: Historical and Paleoenvironmental Perspectives, edited by E. Domack, pp. 79-92, AGU, Washington, D. C.

Schmidt, S., H. Howa, A. Diallo, J. Martín, M. Cremer, P. Duros, C. Fontanier, B. Deflandre, E. Metzger, and T. Mulder (2014), Recent sediment transport and deposition in the Cap-Ferret Canyon, South-East margin of Bay of Biscay, Deep Sea Res., Part II, 104, 134-144.

Shevenell, A. E., and J. P. Kennett (2002), Antarctic Holocene climate change: A benthic foraminiferal stable isotope record from Palmer Deep, Paleoceanography, 17(2), 1019, doi:10.1029/2000PA000596.

Shevenell, A. E., A. E. Ingalls, E. W. Domack, and C. Kelly (2011), Variability west of the Antarctic Peninsula, Nature, 470(7333), $250-254$.

Shindell, D. T., and G. A. Schmidt (2004), Southern Hemisphere climate response to ozone changes and greenhouse gas increases, Geophys. Res. Lett., 31, L18209, doi:10.1029/2004GL020724.

Simmonds, I., and K. Keay (2000), Variability of Southern Hemisphere extratropical cyclone behavior, 1958-97, J. Clim., 13(3), 550-561.

Sjunneskog, C., and Taylor, F. (2002), Postglacial marine diatom record of the Palmer Deep, Antarctic Peninsula (ODP Leg 178, Site 1098) 1. Total diatom abundance, Paleoceanography, 17(3), PAL 4-1, doi:10.1029/2000PA000563.

Smith, D. A., and J. M. Klinck (2002), Water properties on the west Antarctic Peninsula continental shelf: A model study of effects of surface fluxes and sea ice, Deep Sea Res., Part II, 49(21), 4863-4886.

Smith, R. C., et al. (1999), Marine ecosystem sensitivity to climate change, BioScience, 49(5), 393.

Spence, P., S. M. Griffies, M. H. England, A. M. C. Hogg, O. A. Saenko, and N. C. Jourdain (2014), Rapid subsurface warming and circulation changes of Antarctic coastal waters by poleward shifting winds, Geophys. Res. Lett., 41, 4601-4610, doi:10.1002/2014GL060613.

Stammerjohn, S. E., and R. C. Smith (1996), Spatial and temporal variability of western Antarctic Peninsula sea ice coverage, in Foundations for Ecological Research West of the Antarctic Peninsula, edited by R. M. Ross, E. E. Hofmann, and L. B. Quetin, pp. 81-104, AGU, Washington D. C.

Stammerjohn, S. E., D. G. Martinson, R. C. Smith, X. Yuan, and D. Rind (2008), Trends in Antarctic annual sea ice retreat and advance and their relation to El Niño-Southern Oscillation and Southern Annular Mode variability, J. Geophys. Res., 113, C03S90, doi:10.1029/2007JC004269.

Steig, E. J., D. P. Schneider, S. D. Rutherford, M. E. Mann, J. C. Comiso, and D. T. Shindell (2009), Warming of the Antarctic ice-sheet surface since the 1957 International Geophysical Year, Nature, 457(7228), 459-62.

Sterken, M., S. J. Roberts, D. A. Hodgson, W. Vyverman, A. L. Balbo, K. Sabbe, S. G. Moreton, and E. Verleyen (2012), Holocene glacial and climate history of Prince Gustav Channel, northeastern Antarctic Peninsula, Quat. Sci. Rev., 31, 93-111.

Stewart, A. L., and A. F. Thompson (2015), Eddy-mediated transport of warm Circumpolar Deep Water across the Antarctic Shelf Break, Geophys. Res. Lett., 42, 432-440, doi:10.1002/2014GL062281.

Stuiver, M., P. J. Reimer, and R. W. Reimer (2005), CALIB 5.0[WWW program and documentation].

Taylor, F., and C. Sjunneskog (2002), Postglacial marine diatom record of the Palmer Deep, Antarctic Peninsula (ODP Leg 178 , Site 1098) 2. Diatom assemblages, Paleoceanography, 17(3), 8001, doi:10.1029/2000PA000564.

Taylor, F., J. Whitehead, and E. Domack (2001), Holocene paleoclimate change in the Antarctic Peninsula: Evidence from the diatom, sedimentary and geochemical record, Mar. Micropaleontol., 41(1-2), 25-43.

Tokarczyk, R. (1987), Classification of water masses in the Bransfield Strait and southern part of the Drake Passage using a method of statistical multidimensional analysis, Polish Polar Res., 41, 629-641.

Turner, J., S. Leonard, T. A. Lachlan-Cope, and G. J. Marshall (1998), Understanding Antarctic Peninsula precipitation distribution and variability using a numerical weather prediction model, Ann. Glaciol., 27, 591-596.

Turner, J., S. A. Harangozo, G. J. Marshall, J. C. King, and S. R. Colwell (2002), Anomalous atmospheric circulation over the Weddell Sea, Antarctica during the Austral summer of 2001/02 resulting in extreme sea ice conditions, Geophys. Res. Lett., 29(24), 2160, doi:10.1029/2002GL015565.

Turner, J., S. R. Colwell, G. J. Marshall, T. A. Lachlan-Cope, A. M. Carleton, P. D. Jones, V. Lagun, P. A. Reid, and S. lagovkina (2005), Antarctic climate change during the last 50 years, Int. J. Climatol., 25(3), 279-294.

Vaughan, D. G., G. J. Marshall, W. M. Connolley, C. Parkinson, R. Mulvaney, D. A. Hodgson, J. C. King, C. J. Pudsey, and J. Turner (2003), Recent rapid regional climate warming on the Antarctic Peninsula, Clim. Change, 60(3), 243-274.

Venegas, S. A., and M. R. Drinkwater (2001), Sea ice, atmosphere and upper ocean variability in the Weddell Sea, Antarctica seasons as the Ice Station Weddell with the SSM/I series, J. Geophys. Res., 106(C8), 16,747-16,765, doi:10.1029/2000JC000594.

Vimeux, F., V. Masson, J. Jouzel, J. R. Petit, E. J. Steig, M. Stievenard, R. Vaikmae, and J. W. C. White (2001), Holocene hydrological cycle changes in the Southern Hemisphere documented in East Antarctic deuterium excess records, Clim. Dyn., 17(7), 503-513.

Whitehead, J. M., S. Wotherspoon, and S. M. Bohaty (2005), Minimal Antarctic sea ice during the Pliocene, Geology, $33(2), 137$.

Willmott, V., E. W. Domack, M. Canals, and S. Brachfeld (2006), A high resolution relative paleointensity record from the Gerlache-Boyd paleo-ice stream region, northern Antarctic Peninsula, Quat. Res., 66(1), 1-11.

Yuan, X. (2004), ENSO-related impacts on Antarctic sea ice: A synthesis of phenomenom and mechanisms, Antarct. Sci., 16(4), 415-425.

Zhou, M., P. P. Niiler, and J.-H. Hu (2002), Surface currents in the Bransfield and Gerlache Straits, Antarctica, Deep Sea Res., Part I, 49(2), 267-280.

Zielinski, U., and R. Gersonde (1997), Diatom distribution in Souther Ocean surface sediments (Atlantic sector): Implications for paleoenvironmental reconstructions, Palaeogeogr. Palaeoclimatol. Palaeoecol., 129, 213-250. 